\title{
WHAT THE NUMBERS REALLY TELL US ABOUT THE DECLINE OF THE OPIUM REGIE
}

\author{
Siddharth Chandra ${ }^{1}$
}

\section{Introduction}

Recent quantitative economic studies by Dutch scholars suggest that conscious government policy succeeded in diminishing the scourge of opium in the Netherlands Indies. These studies are in stark contrast to qualitative research by American scholars, which suggests the dominance of the profit motive in the implementation of government policy toward opium. In this paper, it is shown that the quantitative evidence, when analyzed in historical context, supports the American view. I will demonstrate, in particular, that the Opium Regie was an extremely lucrative government enterprise, and that, contrary to its stated aims, the government did little to use the profits of this enterprise to stamp out the opium problem. In the final analysis, Indonesia has the Great Depression, and not the Opium Regie, to thank for the decline of opium consumption in the years prior to her independence.

\section{The Origins of the Opium Regie}

The Opium Regie was a centralized system for the processing, distribution, and sale of processed opium in the Netherlands Indies. The origins of the Regie lie in the

\footnotetext{
${ }^{1}$ Support from the Asian Studies Program at the University of Pittsburgh, comments on different parts of this research from Anne Foster, James Rush, seminar participants at the University of Pittsburgh, Carnegie Mellon University, and the RAND Corporation, and the research assistance of Miranda Beshara and Mahendra Lawoti are gratefully acknowledged.
} 
1880 s. $^{2}$ Prior to this time, the government of the Netherlands Indies had used a system of revenue farms to earn revenue from the sale of opium. ${ }^{3}$ Regional monopoly rights for the processing and sale of government-supplied raw opium had been auctioned to the highest bidder. During the 1880s, however, the Netherlands Indies economy experienced a severe recession. ${ }^{4}$ This recession had a damaging effect on the operation of the opium revenue farms, especially in Java. A number of opium farms were unable to pay their dues to the government, a situation which led to declines in government revenue. This partly motivated the subsequent outcry against abuses associated with the opium farm system, including perceived increases in the level of indebtedness of opium consumers at the hands of Chinese moneylenders. 5

As a result, a coalition of interests developed, which was strong enough to initiate a thorough re-evaluation of the system of manufacture and sale of opium in the Netherlands Indies. This coalition consisted of two groups. The first advocated the integration of the processing and distribution of opium into a single government-owned entity. The motivation was the appropriation of profits, which had hitherto been garnered by the now-wealthy Chinese opium farmers, but which would now accrue to the government. The second group had humanitarian concerns. Members hoped, somewhat naively, that by taking control of the processing and sale of opium and eliminating the opium farms, the government would soon eliminate the consumption of opium and the accompanying problems of addiction and indebtedness. The convergence of fiscal and ethical interests led to the creation of the Opium Regie. In the context of the history of Indonesia, the anti-opium-farm movement was a manifestation of a broader change in public opinion among the Dutch leading up to the Ethical period (so called because it led to the creation of a variety of institutions that were supposed to improve the condition of Indies subjects, and thereby to correct perceived injustices). The anti-opium-farm movement had the support of European elements of the plantation and business community and of those Dutch who had genuine humanitarian concerns. It was resisted by a number of opium-farmers of Chinese descent, who had become powerful and wealthy in the business, and by some European planters who resented the new government presence close to their estates.

\footnotetext{
2 This introduction follows James R. Rush, Opium to Java: Revenue Farming and Chinese Enterprise in Colonial Indonesia, 1860-1910 (Ithaca and London: Cornell University Press, 1990), pp. 217-41, the most systematically researched summary to date of the debate that led to the formation of the Opium Regie and its goals.

${ }^{3}$ For discussions of revenue farmers and farming in Java, see, for example, Howard Dick, "Oei Tiong Ham," in The Rise and Fall of Revenue Farming: Business Elites and the Emergence of the Modern State in Southeast Asia, eds. John Butcher and Howard Dick (New York, N.Y.: St. Martin's Press, 1993), pp. 272-280, and James Rush, Opium to Java.

${ }^{4}$ This recession was partly related to the sugar crisis of 1884-1885. See P. Creutzberg, Changing Economy in Indonesia: A Selection of Statistical Source Material from the Early 19th Century up to 1940, vol. 4: Rice Prices (The Hague: Martinus Nijhoff, 1978), p. 28, for a brief account of the sugar crisis and its impact on the economy.

${ }^{5}$ The term "Chinese," imprecise as it is in this context, will be used out of convenience to refer to people of Chinese descent. An interesting parallel trend in popular opinion against opium developed in the US at this time. See T. D. Crothers, "Some New Studies of the Opium Disease," Journal of the American Medical Association XVIII (January-June 1892): 227-33, for an informed (by the standards of the time) discussion of the subject.
} 
The Opium Regie involved a complete overhaul of the system of processing and sale of opium. This included, first, the replacement of small local opium-farm factories with a single modern central factory in Batavia. This factory produced opium of standard quality, thereby eliminating the problem of adulteration. The first factory was built in 1893, only to be replaced by a larger factory in 1901 as the scope of the Regie expanded. With the major exception of raw opium destined for the government factory in Batavia, the import of opium was banned, and government resources were invested in enforcing the ban. Second, the staff members of the local, privately run opium farms were replaced with local bureaucrats. Third, the coordination of processing and distribution of opium was brought under the supervision of a central bureau within the Finance Department. The regional distribution network of the Regie consisted, at its hub, of a regional depot, run by a European, and a comprehensive network of regional official retail stores. Interestingly, and seemingly contrary to the stated aim of reducing opium consumption in Java, the Regie operated at least as many-and most likely, more--stores than were in operation during the opium farm era. 6 The opium that was purchased at these stores could then be taken to an opium den where, for a small fee, the smoker would receive the equipment and a place in which to smoke. In effect, the Opium Regie involved the replacement of a lucrative and powerful Chinese business with a lucrative and more powerful government business. With a master-stroke, the Netherlands Indies authorities had eliminated an expensive (in terms of profits foregone by the treasury) system of Chinese-run processing and distribution to integrate the entire opium sector into one large government-run enterprise. The Opium Regie was first introduced in Madura in 1894. By 1903, the Regie was in force across Java, and by 1914, it had spread throughout the Netherlands Indies.

\section{The Importance of the Opium Regie to the Netherlands Indies Budget}

As Table 1 shows (see below), the Opium Regie contributed significantly to the Netherlands Indies budget. In monetary terms, revenue from opium ranged between 32.6 and 52.6 million Guilders ${ }^{7}$ over the period 1914-1929. Excluding the years 1920 1922 , this revenue fluctuated within a steady band of about ten million Guilders. In percentage terms, however, the importance of revenues from opium relative to the entire budget declined steadily over this period, from 13.5 percent in 1914 to 5.3 percent in $1929 . .^{8}$ This was due to increasing government penetration into the rapidly expanding Netherlands Indies economy, which generated large amounts of revenue, directly or indirectly, from newer sectors of the economy. Although the relative decline

\footnotetext{
6 See James Rush, Opium to Java, p. 220.

7 These figures are not adjusted for inflation.

${ }^{8}$ For comparable figures for other colonies in Southeast Asia, see Anne Foster, "Prohibition as Superiority: Policing Opium in South-East Asia, 1898-1925," The International History Review, XXII.,2 (June 2000 ): 256.

${ }^{9}$ See Column 3 of Table 1 . The newer sectors include the by-then booming rubber sector, and the oil and mining sectors.
} 
104 Siddharth Chandra

Table 1: Contribution of the Opium Regie to the Government Budget

\begin{tabular}{|c|c|c|c|c|c|}
\hline Year & $\begin{array}{c}\text { Opium } \\
\text { Revenue }^{\dagger}\end{array}$ & $\begin{array}{c}\text { Total } \\
\text { Revenue }^{\dagger}\end{array}$ & $\begin{array}{c}\text { Opium \% of } \\
\text { Total }\end{array}$ & $\begin{array}{c}\text { Opium } \\
\text { Profits }(\pi)^{\dagger}\end{array}$ & $\begin{array}{c}\pi \text { as \% of } \\
\text { Opium Rev. }\end{array}$ \\
\hline 1914 & 35.0 & 281.7 & 13.5 & 26.7 & 76 \\
\hline 1915 & 32.6 & 309.7 & 11.2 & 25.2 & 77 \\
\hline 1916 & 35.3 & 343.1 & 10.8 & 28.4 & 80 \\
\hline 1917 & 38.2 & 360.1 & 11.4 & 30.4 & 80 \\
\hline 1918 & 38.8 & 399.7 & 10.2 & 30.1 & 78 \\
\hline 1919 & 42.5 & 543.1 & 8.2 & 33.2 & 78 \\
\hline 1920 & 53.6 & 756.4 & 7.5 & 41.6 & 78 \\
\hline 1921 & 53.3 & 791.8 & 7.1 & 42.1 & 79 \\
\hline 1922 & 44.2 & 752.6 & 6.2 & 34.5 & 78 \\
\hline 1923 & 37.6 & 650.4 & 6.1 & 30.1 & 80 \\
\hline 1924 & 35.3 & 717.9 & 5.1 & 28.1 & 80 \\
\hline 1925 & 36.6 & 753.8 & 5.2 & 28.7 & 78 \\
\hline 1926 & 37.7 & 807.9 & 5.2 & 29.1 & 77 \\
\hline 1927 & 40.6 & 779.1 & 5.7 & 31.4 & 77 \\
\hline 1928 & 42.8 & 835.9 & 5.7 & 34.6 & 81 \\
\hline 1929 & 40.9 & 848.5 & 5.3 & 32.7 & 80 \\
\hline 1930 & 34.5 & 755.6 & 5.3 & 27.1 & 79 \\
\hline 1931 & 25.3 & 652.0 & 4.6 & 19.0 & 75 \\
\hline 1932 & 17.3 & 501.8 & 4.5 & 12.3 & 71 \\
\hline 1933 & 12.7 & 460.6 & 3.7 & 8.6 & 68 \\
\hline 1934 & 11.1 & 455.2 & 3.2 & $7.2^{*}$ & $65^{*}$ \\
\hline 1935 & 9.5 & 466.7 & 2.6 & $6.1 *$ & $64^{*}$ \\
\hline 1936 & 8.9 & 537.8 & 2.2 & $5.7^{*}$ & $64^{*}$ \\
\hline 1937 & 11.5 & 575.4 & 2.5 & $7.7^{*}$ & $67^{*}$ \\
\hline 1938 & 11.9 & 597.1 & 2.6 & $8.0^{*}$ & $67^{*}$ \\
\hline 1939 & 11.5 & 663.4 & 1.7 & $8.6 *$ & $75^{*}$ \\
\hline 1940 & 11.7 & N.A & N.A & $8.5 *$ & $72^{*}$ \\
\hline
\end{tabular}

Sources: For opium, the source data are Dutch East Indies Opiumregie, Verslag betreffende den Dienst der Opiumregıe (Batavia: Landsdrukkerij, 1915-1933) and Dutch East Indies Opium- en Zoutregie, Verslag betreffende de Opium- en Zoutregie en de Zoutwinning (Batavia: Landsdrukkerij, 1934-1940), henceforth referred to as the Opium Reports. For total revenue, the source data are P. Creutzberg, Changing Economy in Indonesia: A Selection of Statistical Source Material from the Early 19th Century up to 1940. Volume 2: Public Finance 1816-1939, (The Hague: Martinus Nijhoff, 1976), p.43-44. The latter source contains data only until 1939.

${ }^{\dagger}$ In millions of current (i.e., not adjusted for inflation) Guilders.

*These figures are derived from the combined accounts of the Opium and Salt Regie. They were computed by subtracting from opium revenue all elements of cost which were totally or partially attributable to the opium section of the Opium and Salt Regie. The numbers, therefore, underestimate the profitability of opium. 
in opium revenues over this sixteen-year period was substantial, the 5 percent share in 1929 was still important for a single activity.

The onset of the crash of 1929, which initiated the Great Depression, brought with it a precipitous drop in opium revenue. Between that year and 1936, when the economy began to pull out of the Depression, revenues shrank further, from 34.6 to 8.9 million Guilders, and the decline in the importance of opium revenue in the government budget continued. As the economy emerged from its slump after 1936, revenues increased to over eleven million Guilders and remained at this level until the beginning of the Second World War.

Throughout the years for which data are available, one fact stands out above the rest. The Opium Regie was extremely profitable. In the pre-Depression years, between 76 percent and 80 percent of the opium revenue was profit (see Column 6 in Table 1). In other words, for every Guilder of cost incurred by the Regie, it made between three and four Guilders in profit! This amounted to a sizable annual windfall for the Netherlands Indies government. Even in the worst years of the Depression, the government was claiming fully 64 percent of its opium revenues as profit. In an enterprise as profitable as this, it is not at all inconceivable that the government would have lacked the will to reduce opium consumption. This raises the important question of the intentions of the government toward the opium enterprise.

\section{Opium Consumption and Policy Responses, 1914-1940}

The most detailed data on the Opium Regie pertain to the period beginning in 1914, when the government became the exclusive legal processor of imported raw opium. ${ }^{10}$ Figure 1 (below) is a plot of sales of opium between 1914 and 1940. Two episodes of decline are visible. The first occurred in 1920-1923, and the second, in 1929-1935. Both can be explained by economic events whose origins were entirely external to the Opium Regie.

The first drop in consumption occurred in 1920-1923. This drop was caused by a general rise in prices, which was accompanied by an increase in the price of opium, from 24.97 to 30.00 Guilders per thail between 1920 and 1921 in Java and Madura, and, more gradually, from 17.02 to 24.36 Guilders per thail between 1920 and 1923 in the Outer Islands. ${ }^{11}$ The rise in the price of opium was motivated at least in part by a rise in the cost of the main raw material at the time, Bengal opium, from 33.96 to 38.90 Guilders per kilogram between 1918 and $1920 .{ }^{12}$ In comparison to other goods,

10 See W. L. Korthals Altes, Changing Economy in Indonesia: A Selection of Statistical Source Material from the Early 19th Century up to 1940, vol. 15: Prices (non-rice) 1814-1940 (The Hague: Martinus Nijhoff, 1994), p. 143.

11 For details of the general price rise, see P. Creutzberg, Rice Prices, p. 29, and W. L. Korthals Altes, Prices (non-rice), p. 18. For opium prices, see W. L. Korthals Altes, Prices (non-rice), p. 142. Prior to reporting weights in grams and kilograms (the 1938-1940 editions of the Opium Reports), the system of recording involved the weights mata, thail, and kati. The conversions were 100 mata $=1$ thail $=38.6$ grams, and 16 thail $=1 \mathrm{kati}$. The currency followed the decimal system, with 100 cents $=1$ Guilder for the entire period.

12 These data are obtained from Dutch East Indies Department van Financien, Opiumfabriek, jaarverslag (Weltevreden: Landsdrukkerij, various). This point will be discussed in more detail in a subsequent section. 
Figure 1: Sales of Regie Opium, 1914-1940

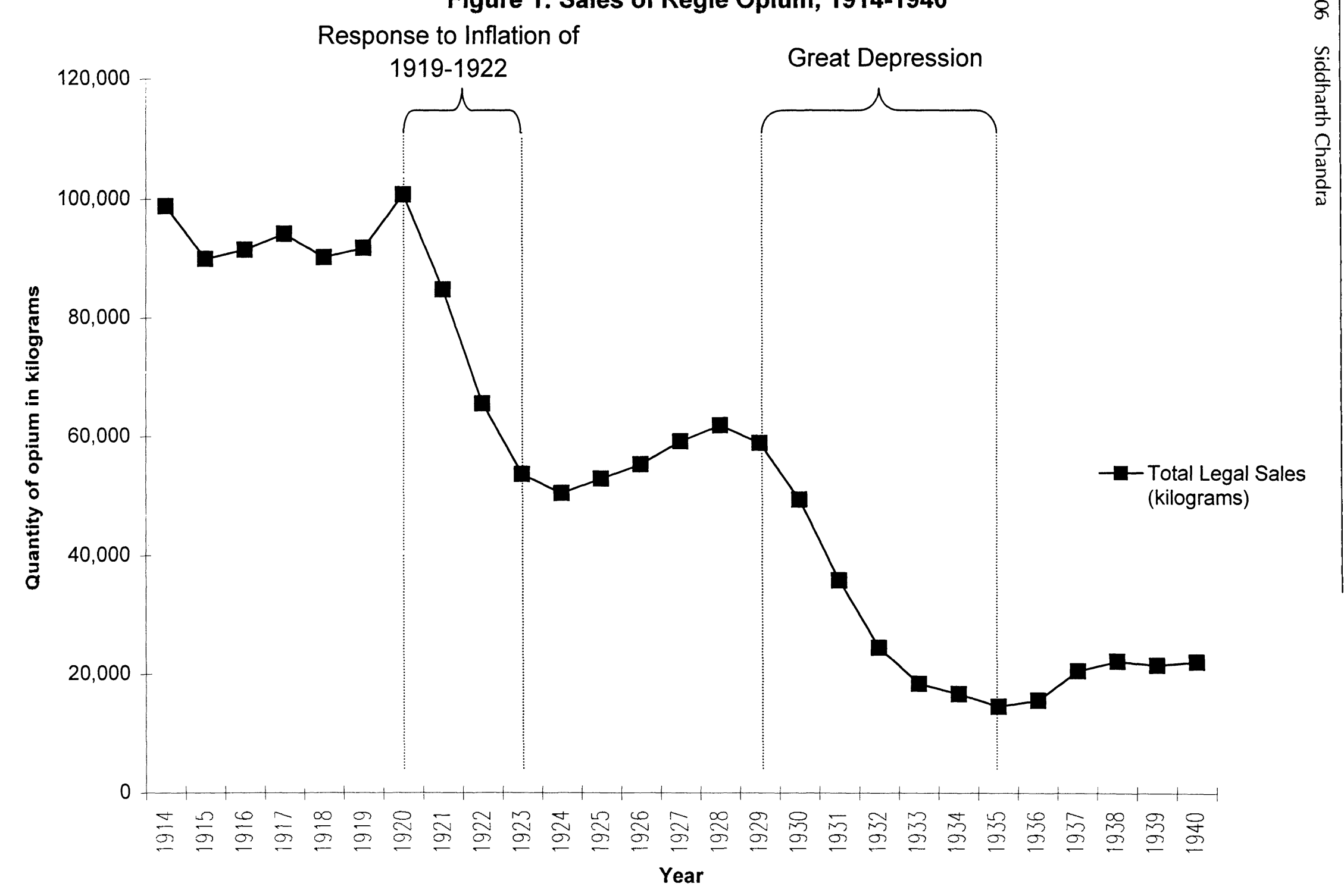


Figure 1a: Seized Contraband Opium, 1915-1940*

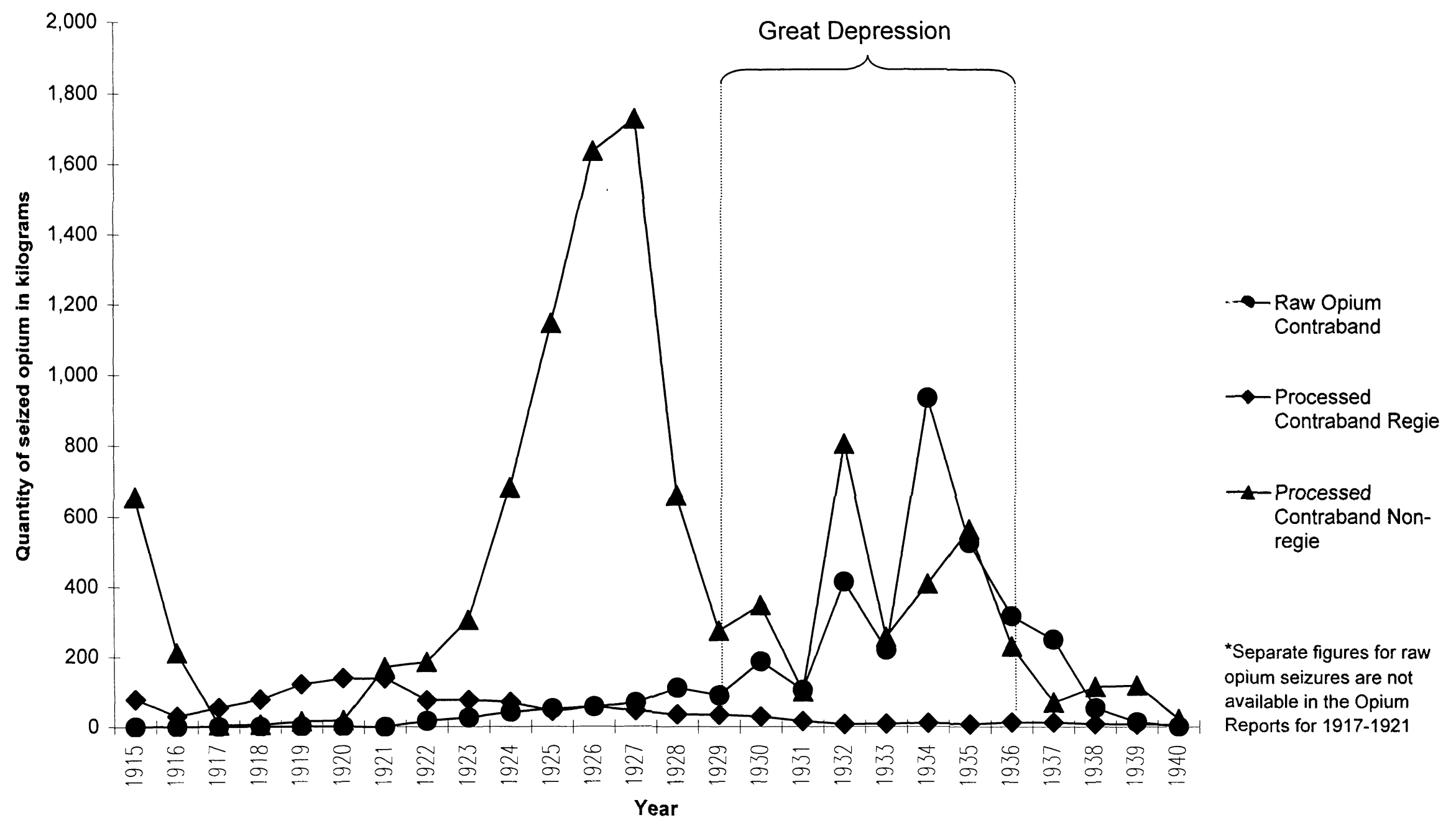




\section{Siddharth Chandra}

however, the price of opium rose less, actually making it cheaper in "real" terms. ${ }^{13}$ It must therefore be concluded that opium consumption fell not because of a rise in the money-denominated price of opium, but because of the larger rise in the general price level, which reduced the overall purchasing ability of subjects. During these crisis years, consumers substituted smuggled opium for legal Regie opium, as evidenced by the spike in seizures (see Figure 1a, above) of contraband opium in the years following the price rise. ${ }^{14}$ The Regie responded to this threat by relaxing its stringent licensing policy with respect to the sale of opium in 1927. This made it easier for users, especially in the Outer Islands, which were more susceptible to smuggling, to purchase and use Regie opium. These two measures, the decrease in the "real" price of opium and the relaxation of the licensing poicy, helped the gradual recovery of sales until the onset of the Great Depression in 1929.

The second drop in consumption occurred between 1929 and 1935, the years of the Great Depression. During this time, the Regie held the price it had been charging since 1921 in Java constant, at thirty Guilders per thail. The price was also relatively stable in the Outer Islands. Figure 2 (below) contains plots of both sets of prices. As the prices of other goods fell sharply, causing the incomes of most Indies subjects to fall in money-denominated terms, opium became increasingly expensive in "real" terms, or in comparison to other items. ${ }^{15}$ Figure $2 a$ (below), which contains a plot of the "real" price of opium for the Chinese, shows that, in terms of purchasing power, the price of opium more than doubled during the Great Depression. ${ }^{16}$ Ironically, then, it was the inaction of the Regie in the face of the Depression that led to the drop in consumption. To the resulting decline, the government responded, somewhat belatedly, by cutting the price of opium in 1936 in Java and Madura (Figures 2 and 2a). This had the effect of jump-starting consumption, ${ }^{17}$ but the beginning of the recovery of the Opium Regie was abruptly halted when the Japanese invaded the Netherlands Indies in 1942.

Because the data for consumption in the Depression years are more detailed than those for the period prior to 1923, a number of interesting phenomena are revealed in the responses of Indies opium users to this second crisis. The first noticeable development is the increase in seizures of contraband opium. In contrast to the spike in seizures of the mid-1920s, which consisted mostly of processed opium, the seizures of the Great Depression contained a much larger component of raw opium (Figure 1a). This was the result of the inability of smokers to purchase the refined and more expensive processed smuggled substitute. A second set of consequences of the

13 In standard economic analysis, the nominal or money-denominated price of a good is considered to have little meaning - consumption is always modeled as being a function of the "real" price of the good.

14 While this spike could also have been driven by increased anti-smuggling enforcement, to the extent that the stable expenditures on enforcement are an indicator, enforcement activity remained fairly constant over this period.

15 A key feature of the Great Depression in the Netherlands Indies was the accompanying deflation, or fall in the general price level (or cost of living). For detailed statistics on this deflation, see Departement van Economische Zaken, Prijzen, Indexcijfers en Wisselkoersen op Java 1913-1937 (Batavia: Centraal Kantoor voor de Statistiek, 1938, Mededeelingen van het Centraal Kantoor voor de Statistiek, No. 146), especially pp. 17-58. The same phenomenon occurred in the US during the Depression.

16 The plot of the "real" price for the indigenous users looks very similar to that for the Chinese.

17 Opium consumption rose 31.9 percent between 1936 and 1937. 
Figure 2: Nominal* Opium Price, 1914-1940

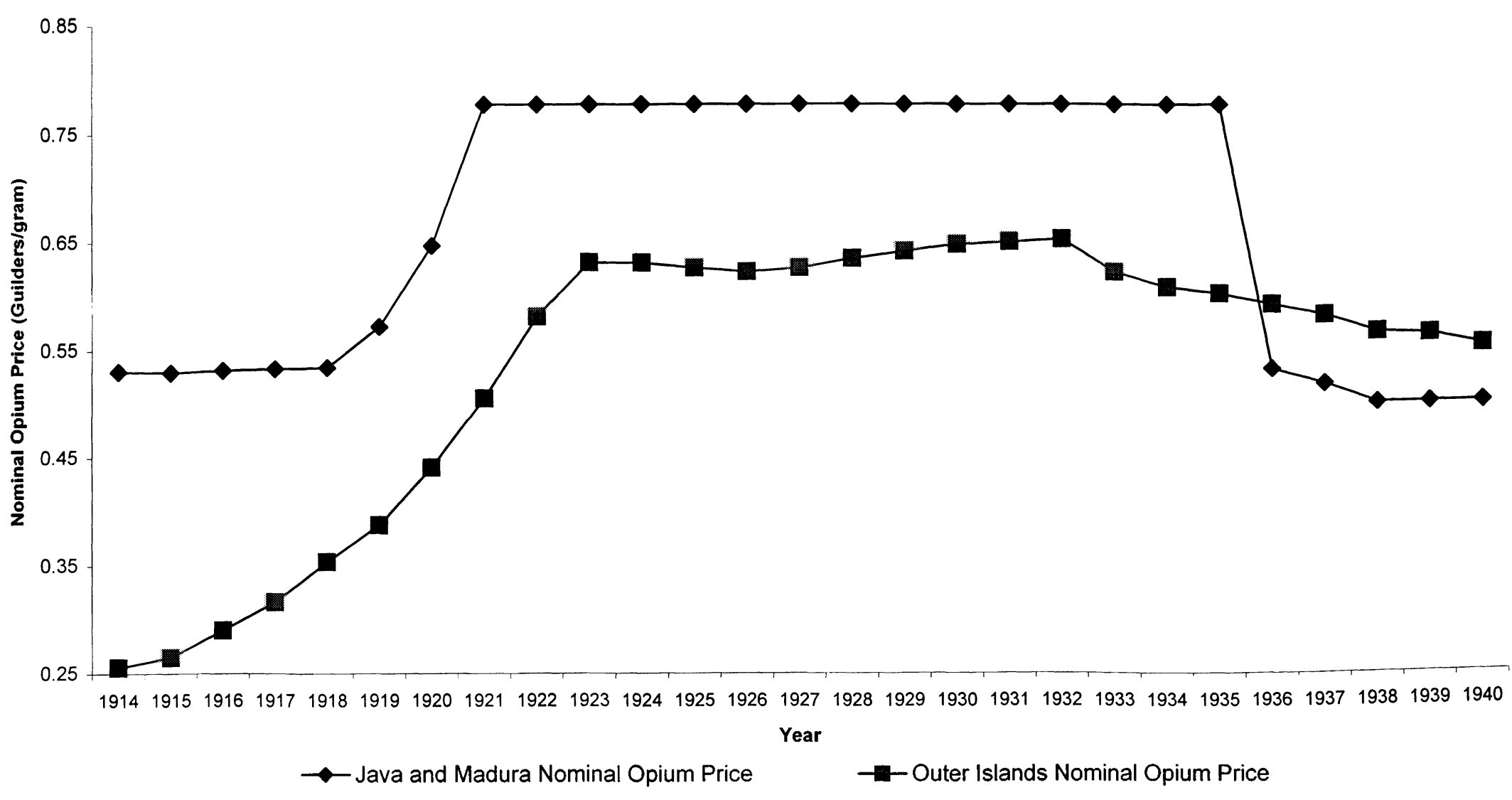

*Not adjusted for inflation.

Source: W.L. Korthals Altes, Changing Economy in Indonesia: A Selection of Statistical Source Material from the Early 19 th Century up to 1940.

Volume 15: Prices (non-rice) 1814-1940 (The Hague: Martinus Nijhoff, 1994), Table 3H, p.142. 
Figure 2a: Real Opium Prices in Java and Madura, 1921-1939*

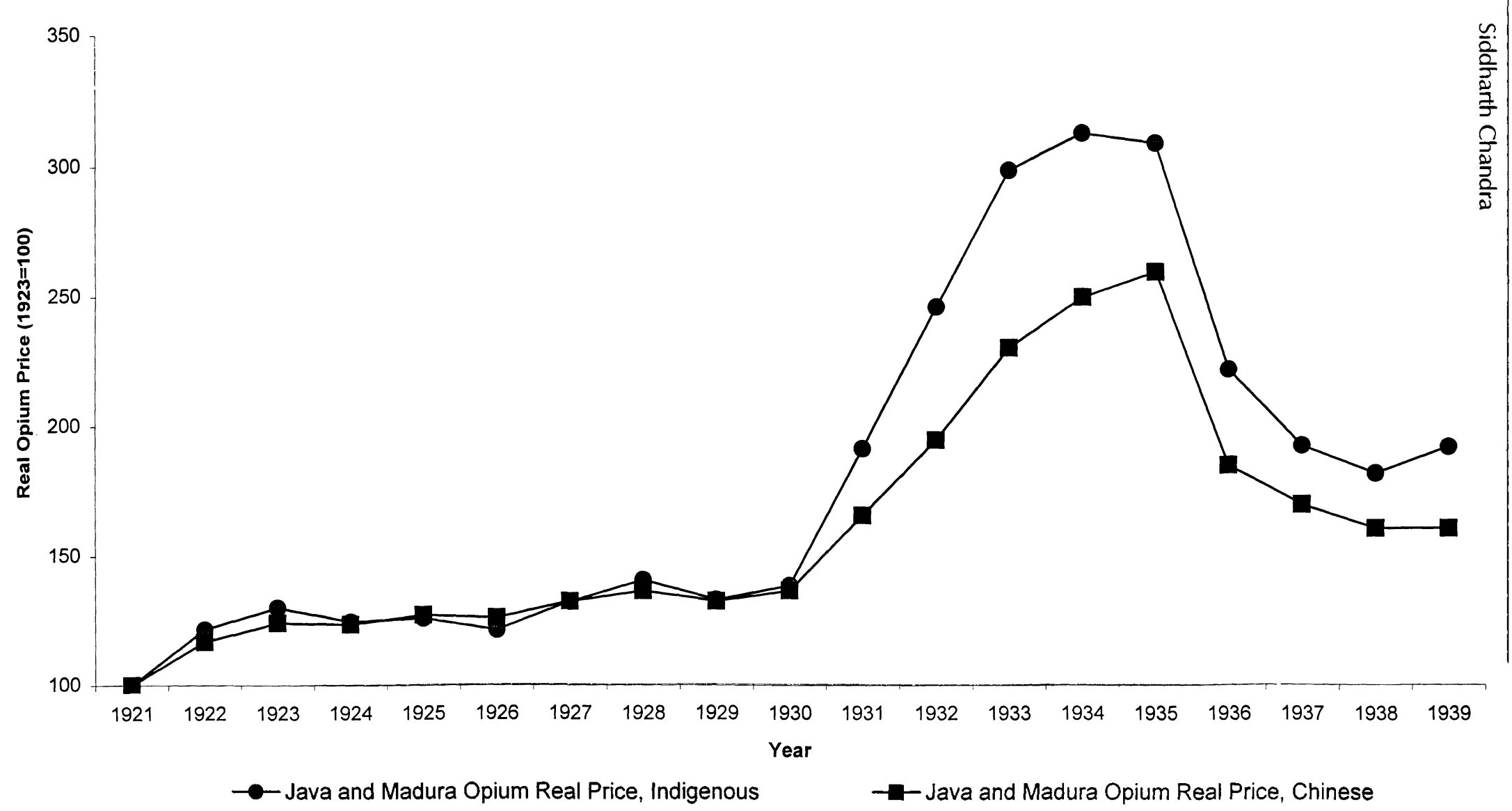

*This plot is an index of the real (inflation-adjusted) price of opium, with the real price in the benchmark year of 1921 set to 100 . Price levels were obtained from J.J. Polak, The National Income of the Netherlands Indies, 1921-1939 (New York: Netherlands and

Netherlands Indies Council of the Institute of Pacific Relations, 1943), Table 16.2, p.51a. Price level data were not available for the years prior to 1921 and after 1939 . 
Depression relates to a large literature on the behavioral aspects of addiction in general and the consumption of opiates in particular. The following section contains a discussion of some of these.

\section{The Great Depression and the Behavior of Opium Users}

The fallout of the Depression included the havoc it wreaked on opium smokers. Table 2 (below) shows the data on patients hospitalized on account of opium addiction. While these figures only began to appear in the Opium Reports in 1932, they show a steep decline in the number of patients in the hospital system in the early 1930s. The percentages in Column 4 of Table 2 show that the patient-load was roughly twice as large in 1932 as it was in the post-Depression years of 1937 and later. This is an indication of the effect of the Depression, and of the fact that it was receding by the mid-1930s. The essence of these figures is captured in Van Otterloo's account of the consequences of opium consumption for users during the Great Depression:

The bond with opium naturally has all sorts of consequences, the foremost being financial:

T. T. L. from Weltevreden stated, on September 24, 1929, that he has a family, with a wife and two children. He smokes six mata ${ }^{18}$ [of opium] per day. His total daily income is 2.80 Guilders. The opium costs 1.80 Guilders. He must support his family with the remaining one Guilder. And the situation in which such families live can be even more unfavorable:

O. L. from Batavia smokes 15 mata of opium per day. This costs him 4.50 Guilders. That leaves him 50 cents per day for living expenses. ${ }^{19}$

Given the total number of opium users, the number of patients handled by the hospitals is minuscule. There is a good reason for this. Van Otterloo, in his typology of opium smokers, mentions three stages in the experience of the opium smoker. ${ }^{20}$ It is evident that the hospitals were handling, for the most part, the small fraction of opium smokers who were in the third stage of consumption. An abbreviated translation of the typology follows:

The first period is consciously initiated by the smoker, and usually lasts a few months, though it can last many years ... he smokes increasing quantities with increasing frequency, but opium has not yet become a vital necessity to him. ... He smokes at set times or occasionally, and . . gives an increasingly large role in his life to opium.

\footnotetext{
18 See footnote 10 for the system of weights in use at the time. As will be discussed later, modern scholarship suggests that this amount is "clearly" addictive.

19 Antoine de Mol van Otterloo, De Opiumschuiver in het Hospitaal: Een Proeve van Klinische Beschrijving (Utrecht: Kemink en Zoon N.V., 1933), p. 58.

${ }^{20}$ Ibid., p. 43.
} 


\section{Siddharth Chandra}

Table 2: Opium addicts handled by the Netherlands Indies health system and total number of opium users, 1932-1940

\begin{tabular}{|c|c|c|c|}
\hline Year & $\begin{array}{c}\text { Addicts } \\
\text { Handled }\end{array}$ & $\begin{array}{c}\text { Total Number } \\
\text { of Users }{ }^{\dagger *}\end{array}$ & $\begin{array}{c}\text { Percentage of } \\
\text { Users Handled }\end{array}$ \\
\hline 1932 & 2,423 & 100,500 & $2.4 \%$ \\
\hline 1933 & 1,681 & 99,400 & $1.7 \%$ \\
\hline 1934 & 1,540 & 83,900 & $1.8 \%$ \\
\hline 1935 & 1,059 & 74,800 & $1.4 \%$ \\
\hline 1936 & 806 & 69,300 & $1.2 \%$ \\
\hline 1937 & 796 & 78,000 & $1.0 \%$ \\
\hline 1938 & 955 & 82,300 & $1.2 \%$ \\
\hline 1939 & 955 & 78,300 & $1.2 \%$ \\
\hline 1940 & 1,052 & 77,300 & $1.4 \%$ \\
\hline
\end{tabular}

Source: Opium Reports, 1932-1940.

${ }^{\dagger}$ Total number of users rounded to the nearest 100 .

"The figure in Column 3 understates the actual number of users. It was common for licensed indigenous buyers to illegally distribute opium to other unlicensed users. For the same reason, the figures in Column 4 overstate the percentages of users in the hospital system. 
The second period, in which he is definitely an opium user, ${ }^{21}$ is of very uneven length ... from five months to fifty years. The time almost never comes when this user frees himself from opium ... [T] [Te association with opium is lifelong, and their lives are considerably shortened by the use of opium.

Over time, a relatively small fraction of the users develop an aversion to opium, and attempt to break their association with it. This is the third period ... the user turns to the hospital ... to resolve the conflict between his psychological aversion to and his physical dependence on opium. ${ }^{22}$

From the above account, it can be inferred that the numbers in Column 2 of Table 2 refer primarily to the third type of user, or the most serious cases of addiction. They suggest, however, parallel consequences of the Depression for the second type of user, whose numbers were much larger. ${ }^{23}$

Van Otterloo's account is interesting for a second reason, namely the difference between users in the first and second periods. Economic models of addiction have been designed to conform to the observation that there exist different "types" of users of addictive substances. 24 These models predict, in particular, the existence of a lowintensity user-type, who is flexible in his consumption habits in comparison to a second user-type, the high-intensity user. In this view of addiction, a distinguishing feature of the intense consumer is his tendency, in response to a change in price or income, to either continue consuming at previous levels or completely stop consuming the addictive substance. Less-intense consumers, on the other hand, tend to adjust the quantities that they consume in response to changes in prices and incomes. Because the data from the Opium Regie are quite detailed and reliable, they can be used to test the predictions of this body of theory.

Table 3 (below) is a characterization of the two official population groups for whom data on opium consumption were collected. ${ }^{25}$ As a population, the Chinese

\footnotetext{
21 The Dutch word, "opiumschuiver," conveys the sense of a regular user rather than that of a casual user.

22 Van Otterloo, De Opiumschuiver, p. 43.

23 This first-hand description is in stark contrast to the conclusion in Jan C. Van Ours, "The Price Elasticity of Hard Drugs: The Case of Opium in the Dutch East Indies, 1923-1938," Journal of Political Economy 103,2 (1995): 278, that opium was "not very addictive."

${ }^{24}$ See, for example, Gary S. Becker and Kevin M. Murphy, "A Theory of Rational Addiction," Journal of Political Economy 96 (August 1988): 675-700.

25 The two groups are the indigenous people and the Foreign Asiatics, the majority of whom were Chinese. The results of the 1920 census of the Netherlands Indies suggest that the Chinese outnumbered other Asians in the Foreign Asiatics category by a ratio of about 9:1 on average. To be exact, in Java and Madura, there were 384,218 Chinese and 27,806 Arabs, accounting for 92.5 percent and 6.7 percent of the Foreign Asiatics category respectively. The equivalent figures for the Outer Islands were 425,429 Chinese ( 92.3 percent) and 17,115 Arabs (3.7 percent). These figures were reported in later editions of the Koloniale Verslagen, such as the 1931 edition, pp. 34-35. Full citation: Department van Zaken Oversee, Verslag van Bestuur en Staat van Nederlandsch-Indie over het Jaar 1931 (Batavia: Landsdrukkerij, 1931). For simplicity, and in accordance with standard statistical practice, Foreign Asiatics will be referred to as Chinese. Interestingly, in Van Ours, "The Price Elasticity," cost of living figures for the indigenous people are used to analyze data on the Chinese, when the relevant cost of living data for the Chinese (provided under the category "Foreign Asiatics") are provided in the same source. This renders the analysis of the Chinese data in that study incorrect.
} 


\section{Siddharth Chandra}

Table 3: A characterization of opium users in the Netherlands Indies, 1923-1940

\begin{tabular}{|l|c|c|}
\hline & Chinese & Indigenous \\
\hline Mean Consumption (Intensity) & $633 \mathrm{~g} / \mathrm{yr}$ & $188 \mathrm{~g} / \mathrm{yr}$ \\
\hline Responsiveness to Price* & -0.93 & -0.87 \\
\hline $\begin{array}{l}\text { \% of Price Response Due to } \\
\text { Change in Intensity }\end{array}$ & $54 \%$ & $71 \%$ \\
\hline $\begin{array}{l}\text { \% of Price Response Due to } \\
\text { Number of Users }\end{array}$ & $46 \%$ & $29 \%$ \\
\hline $\begin{array}{l}\text { Responsiveness to Income* } \\
\% \text { of Income Response Due to } \\
\text { Change in Intensity }\end{array}$ & 1.99 & 1.06 \\
\hline $\begin{array}{l}\text { Nof Income Response Due to } \\
\text { Number of Users }\end{array}$ & $41 \%$ & $10 \%$ \\
\hline
\end{tabular}

Source: Mean consumption, from Opium Reports, various. Responsiveness estimates, from Siddharth Chandra, "The Great Depression, Cold Turkey, and the Price and Income Elasticities of a Hard Drug: Opium Consumption in the Netherlands Indies," (Pittsburgh: Graduate School of Public and International Affairs, University of Pittsburgh, February 2000. GSPIA Working Paper PIA 015), Table 5, p. 25.

*These numbers are elasticities, as defined earlier in the text. 
were clearly more intense consumers than their indigenous comrades. ${ }^{26}$ To quote Rush in the context of the Chinese users, ". . . most of the severest addicts then ... appear to have been the Chinese ..." 27 The mean of per-user opium consumption for the Chinese was 634 grams per year. ${ }^{28}$ At a conservatively low morphine content of ten percent, this translates to 63.4 grams or 63,400 milligrams (mg.) of morphine per year. ${ }^{29}$ Averaged over 365 days, this gives a daily per capita consumption of 173.69 mg. of morphine. This is almost three times the amount that is "clearly" addictive. ${ }^{30}$ We also know that morphine is used today as a pain-killer for patients with advanced cancers and other severely painful ailments. For example, the standard handbook for physicians in the US today mentions a standard intravenous dosage of ten mg. every four hours, for a total of sixty $\mathrm{mg}$. per day. ${ }^{31}$ Physical dependence on the drug resulting from prolonged use is widely recognized, and addiction generally sets in rapidly. ${ }^{32}$ To quote the UNDCP, "sought-after effects" include a "sense of well being by reducing tension, anxiety and depression; euphoria, in large doses warmth, contentment, relaxed detachment from emotional as well as physical distress," and "relief from pain (analgesia)." 33 "Long-term effects" include, among a host of other things, "rapid development of tolerance and physical and psychological dependence" and, in the case of "abrupt withdrawal," "moderate to severe withdrawal syndrome which is generally comparable to a bout of influenza (with cramps, diarrhea, running nose, tremors, panic, chills, and sweating, etc.)." 34 Keeping in mind the fact that inhaled morphine is about as bio-available (efficiently absorbed) as intravenously introduced morphine, modern medical standards suggest that $173.69 \mathrm{mg}$. of inhaled morphine per day will very likely "hook" a person over the course of a few weeks, let alone an entire year. Given this evidence, it is safe to infer that addiction to opium must have been a

${ }^{26}$ In terms of numbers of users, in 1923, the first year for which official numbers of users are available, there were 14,393 users in Java and Madura, and 42,287 users in the Outer Islands. As a fraction of the Chinese population in 1920, the closest year for which these data are available, these translate to 3.75 percent for Java and Madura and 9.94 percent for the Outer Islands.

27 Rush, Opium to Java, p. 29.

28 This was computed by using region-year observations of per-user consumption for the period 1923-1940 for twenty-two regions of the Netherlands Indies.

29 This is an approximation. For studies of the content of opium in the Netherlands Indies, see J. Haak, Opiumregie met normaal-tjandoe (Samarang: G.C.T. van Dorp, 1889), pp. 15, 53, and Bijlage A, p. 58, and Tj. J. Addens, De verspreiding van de opium cultuur en de handel in opium (The spread of opium cultivation and opium trade) (Haarlem: Joh. Enschede en zonen, 1939), for example.

30 See John C. Kramer, "Speculations on the Nature and Patterns of Opium Smoking," Journal of Drug Issues (Spring 1979): 247-255, as quoted in Rush, Opium to Java, p. 38. The daily level considered to be "clearly" addictive is $60 \mathrm{mg}$, while levels of $20-30 \mathrm{mg}$. are "mildly" addictive.

31 See Kurt J. Isselbacher, Eugene Braunwald, Jean D. Wilson, Joseph B. Martin, Anthony S. Fauci, and Joseph B. Martin eds., Harrison's Principles of Internal Medicine: Companion Handbook (New York: McGraw Hill, February 1994, 13th edition), Tables1-2, p. 3.

32 For a brief but informative description of opium and opiates, see the United Nations International Drug Control Program (UNDCP), at http: $/ / 193.81 .61 .210 /$ and especially the files on opium, at http://193.81.61.210/adhoc/terminology and information on drugs/. For the purposes of this study, the most relevant files are "opium-1.htm" to "opium-6.htm."

33 UNDCP, http://193.81.61.210/adhoc/terminology and information on drugs/opium-5.htm.

34 UNDCP, ibid. 
116 Siddharth Chandra

serious issue for the Chinese. The corresponding calculation ${ }^{35}$ for the indigenous users yields a daily morphine consumption of $51.51 \mathrm{mg}$., which is between the "mildly" and "clearly" addictive levels.

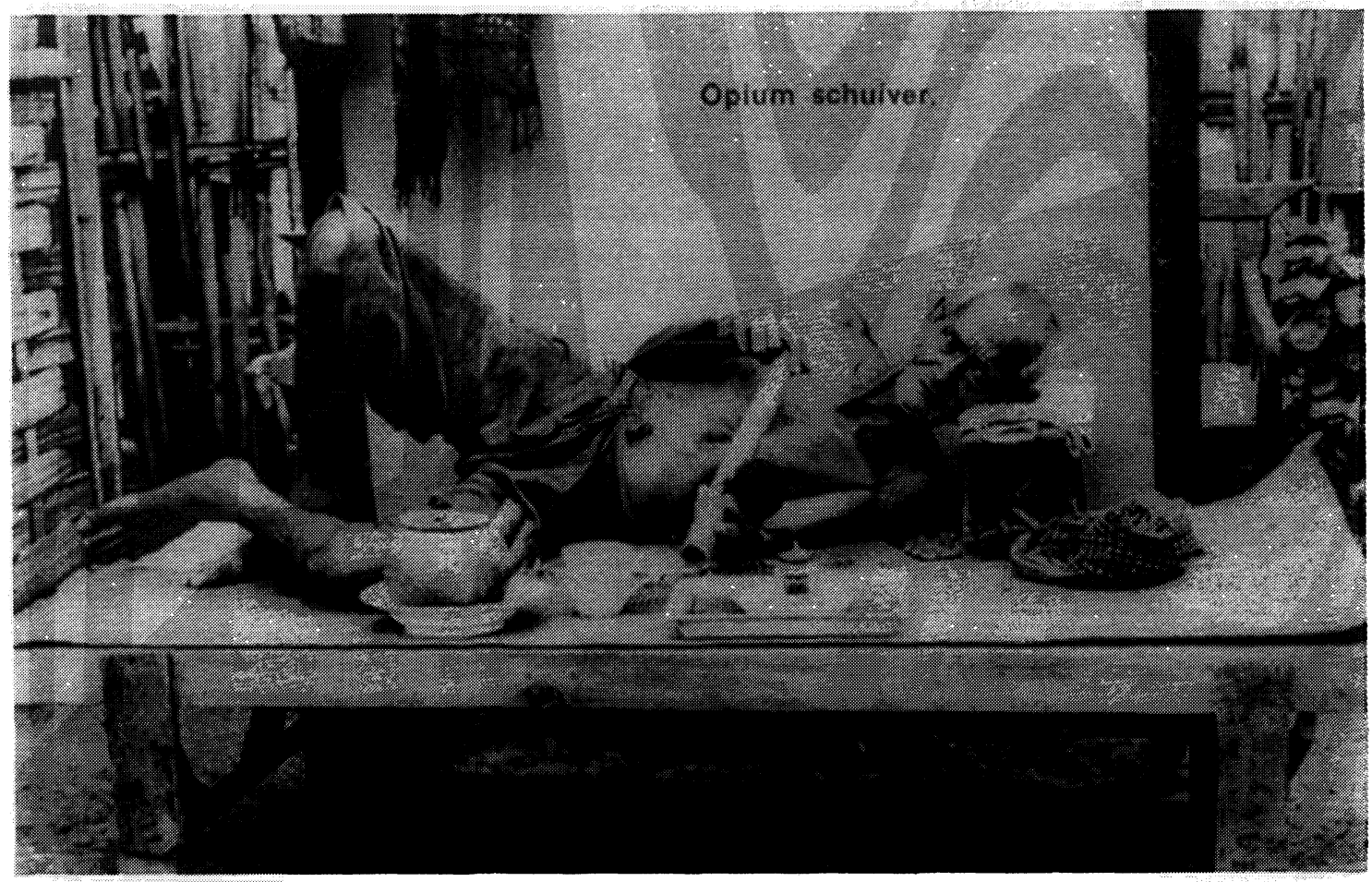

Opium Smoker.

Source: Postcard by G. Kolff and Company, Batavia, circa 1920. Photographer unknown.

From an image scanned by Anton Stikkelman.

Using statistical methods, it is possible to examine the effects of changes in the price of opium on the consumption of opium. ${ }^{36}$ This is done by computing a price elasticity, which is an estimate of the percentage change in consumption of opium in response to a 1 percent rise in price. In Table 3, we see that populations of Chinese and indigenous users responded to a 1 percent increase in the price of opium by reducing their aggregate consumption by 0.93 percent and 0.87 percent respectively. It

35 This is derived from a region-year mean per capita consumption of 188 grams of opium.

${ }^{36}$ For details of the methods used, see Siddharth Chandra, "The Great Depression, Cold Turkey, and the Price and Income Elasticities of a Hard Drug: Opium Consumption in the Netherlands Indies," Graduate School of Public and International Affairs, Working Paper No. PIA015, University of Pittsburgh, February 2000. Located at http://www.pitt.edu/ wpseries. 
is also possible to apportion this elasticity into responses due to changes in intensity of consumption (i.e., how much users adjusted their levels of consumption in response to the change in price) and changes in numbers of users (i.e., how much of the aggregate change in opium consumption was due to users leaving or entering the market for opium). As the theory predicts, the more intense Chinese populations showed a relatively smaller ( 54 percent of the total response) intensity response than did the less-intense indigenous smokers (71 percent). The responses to changes in incomes strengthen this finding. The income elasticity, which is an estimate of the percentage change in consumption of opium in response to a 1 percent rise in income, shows that, for the indigenous users, 90 percent of the income response in aggregate consumption was due to intensity adjustments. The corresponding figure for the Chinese was only 59 percent. In sum, these findings support some of the predictions of economic theories of addiction. More importantly for the purpose of this study, they suggest that the consumption of opium was quite sensitive to changes in price and income. Because the Great Depression was one such episode, this raises a key question about the decline of the Opium Regie-was it a triumph of enlightened drug policy, as seems to be the implication of recent economic research, or was it a historical accident, brought about by the ravages of inflation (1920-1923) and the Great Depression (1929-1936)?

\section{The Decline of Opium Consumption: Policy Triumph or Historical Accident?}

There are two schools of thought on the motives underlying the Opium Regie. The first school, exemplified in the work of Rush, one of the few non-Dutch scholars to have worked on the Opium Regie, views the Ethical rhetoric of the Regie as being inconsistent with its actions. ${ }^{37}$ These actions, it is argued, reveal a predominantly commercial motive underlying the operation of the Opium Regie. The second school, which includes the work of Jan C. van Ours, attributes substantial credibility to Regie rhetoric. ${ }^{38}$ This school interprets the actions and outcomes of the Regie as being consistent with its stated Ethical goal: namely, the reduction, if not eradication, of the opium problem.

\footnotetext{
37 See Rush, Opium to Java, "The Opium Regie and Ethical Java," Chapter 11, pp. 217-241. For a comparative study of drug policy in colonial Southeast Asia, see Foster, "Prohibition as Superiority."

38 See, for example, Van Ours, "The Price Elasticity,"pp. 261-279; Eric W. van Luijk and Jan C. van Ours, "On the determinants of opium consumption: an empirical analysis of historical data," CentER Discussion Paper No. 9863, Tilburg University, June 1998; and Eric W. van Luijk and Jan C. van Ours, "How Government Policy Affects the Consumption of Hard Drugs: The Case of Opium in Java, 1873-1907," CentER Discussion Paper No. 9865, Tilburg University, June 1998, forthcoming in the Journal of Economic History. In this third paper, the authors use data from two different regimes, the opium-farm system and the early Opium Regie, to show that the "change in government policy had a substantial negative effect on opium consumption" (Abstract, p. 1). A part from the essential incomparability of the data across these two regimes, the study ignores the fact that by 1914 , the annual consumption of high morphine-content opium was at the 100,000 kilograms per year level at which low morphine-content opium was being consumed in the 1870 s, and well above the 60,000 kilograms per year level at which this diluted opium was being consumed in the years just prior to the transition to the Opium Regie. The main policy implication of that study, that controlled legalization leads to a decline in consumption, does not, therefore, follow from the analysis.
} 
118 Siddharth Chandra

The characterization of the Opium Regie in Van Ours, "Price Elasticity," leads the reader to believe that the Regie operated in the sole interest of the subjects of the Netherlands Indies. ${ }^{39}$ In this section, the contradictions between this view and that of Rush will be explained. The findings of this study are, furthermore, consistent with Rush's view of the early Regie; the Regie continued to operate like a profit-maximizing monopolist in the market for an addictive good. This point has been entirely neglected in the preceding economic analyses of the Opium Regie.

Because this section seeks to interpret the actions of the Opium Regie, it is important to characterize the behavior of the Regie as it pertains to the pricing and sale of opium. In the years following the inception of the Opium Regie, opium in the Netherlands Indies was the most expensive opium in the world. According to Rush, it was sold for about ten times the price of opium in Singapore in $1903 .{ }^{40}$ Official Dutch policy claimed that this high price was imposed in order to restrict opium consumption in the Netherlands Indies for ethical reasons. A sense of ethical responsibility was not, however, the overriding reason for the prolonged existence of the Regie. During the heated debates on the pros and cons of the opium-farm system, debates which took place during the 1880 s and after, the most influential report on the subject of the policy implications of a new Regie arrangement, the Groeneveldt report, took a commercial approach to the opium question. The author recommended that (a) the supply of opium not be artificially restricted, (b) the state ensure, using an efficient land- and marine-based enforcement system, that smuggling offer no competition to the government product, and (c) that the government sell the opium at a high fixed price to users. The high prices, it was suggested, would discourage addiction, but this beneficial effect was mentioned more as a by-product of the central profit-maximizing goal. As Rush asserts, the Groeneveldt report

... offered the hope that the Netherlands might enjoy its opium revenues even more abundantly without the farms and without the Chinese. The Groeneveldt report irrevocably tilted opinion within the government in the direction of a regie. ${ }^{41}$

More telling than the principles of the Regie, however, were its actions. Van Ours, writing on the establishment of the Regie, states that

[I]f opium smoking was almost absent, the sale of legal opium - if there was any - was stopped, and the use of opium was actually forbidden. ${ }^{42}$

On the other hand, Rush uses the case of the large Priangan residency in West Java to demonstrate that while

[T]he Forbidden Areas had been a hallowed part of the opium farm system to which the Dutch had pointed for years as evidence of their good intentions vis-àvis opium ... [M]uch to the consternation of those who viewed the Opium Regie

\footnotetext{
271, 273.

${ }^{40}$ Rush, Opium to Java, p. 226.

41 Ibid., p. 210.

42 Van Ours, "Price Elasticity," p. 266.
}

${ }^{39}$ A substantial portion of that paper is devoted to discussion of the Opium Regie, its goals, and the historical context of the subsequent analysis. See, for example, Van Ours, "Price Elasticity," pp. 262-268, 
as an Ethical ${ }^{43}$ vehicle for the gradual elimination of opium smoking, regie officials dismantled several of Java's Forbidden Areas. ${ }^{44}$

Van Ours suggests that the official principles of the Opium Regie were translated into action, as in

Not only was the licensing and registration system applied to curtail the number of opium users, it was also used to limit the amount of opium that users consumed. The quantities sold in the opium shops of the state were limited in size. Users were not permitted to buy more than once a day . . ${ }^{45}$

On the other hand, Rush, drawing on detailed archival research, states

... [T] VOC $^{46}$ spirit had survived the Ethical gale. When sales declined or failed to equal those of the preceding farm, officials went to great lengths to justify the falling revenues. When sales increased, reports became jubilant. It occurred to no one to apologize for the boom or to consider measures to reverse the trend. $\mathbf{4 7}$

Rush also quotes an anonymous official in The Hague, who wrote

Reading this report makes one despair for the working of the Regie-there is no indication whatsoever that anyone strives to reduce the use of opium. ${ }^{48}$

In practice, the generation of revenues and profits seems to have been the major concern of officials of the Regie, even in its early days.

Having demonstrated the extreme profitability of the Opium Regie in a previous section, I will now examine, from the perspective of an economist, its key policy actions, including changes in price and licensing policy. The exercise of these policy options reveals a pattern consistent with the behavior of a profit-maximizing monopolist in the market for an addictive good, a point that has not been made in a literature dominated by Dutch scholarship. While aspects of these actions are also consistent with the more charitable Dutch interpretation (i.e., the goal of eradication of opium consumption), a number of facts do not square with that view.

\section{The Economics of the Opium Regie: The Profit Interpretation}

A fundamental characteristic of the Opium Regie was the monopolistic nature of the system. The overt argument for this was the elimination of the trade in smuggled opium, which was seen to be of lower quality than processed Regie opium. Once the monopoly had been established and smuggling controlled, it was argued, the Regie

\footnotetext{
43 The word "Ethical" refers to the Ethical period in the history of Indonesia, described earlier.

44 Rush, Opium to Java, p. 235.

45 Van Ours, "Price Elasticity," p. 267.

46 VOC is the acronym for Verenigde Oost-Indische Compagnie (the United (Dutch) East India Company), which represented the initial and explicitly commercial Dutch interest in what is now Indonesia.

47 Rush, Opium to Java, p. 235.

48 Ibid., p. 241.
} 
would turn its attention inward to the eradication of legal opium consumption. ${ }^{49}$ The government was supposed to use strong anti-smuggling measures to enforce this general policy. To determine the commitment of the Opium Regie to the anti-smuggling effort, we need to turn to the accounts of the Opium Regie.

Table 4 (below) provides a sample balance sheet for the Regie for the year 1925, showing the various cost components. In addition to purchasing processed opium from the factory in Batavia (now Jakarta), the Regie was responsible for the packing, transportation, and distribution of opium, along with other activities such as drug enforcement. For this reason, the final cost of opium included, in addition to the cost of processed opium itself, a number of additional items. Interestingly, a small fraction (at 4.2 percent in 1925, for example) of total cost was allocated to anti-smuggling activities. This allocation was even lower as a fraction of the revenues (at 0.9 percent) or profits (at 1.2 percent) of the Regie, which could, presumably, have been allocated by an Ethically minded organization to the eradication of the problem. What is more, the reason for this relatively small allocation was economic and had nothing to do with the ideal of eliminating smuggling, even when there was plenty of room in the budget to attempt this. As Rush says," . . . by 1903 it was already the consensus that to intercept completely the flow of illegal opium into Java would require exorbitant expenditures." ${ }^{50}$ So, rather than attempt to achieve its stated goal, perhaps by plowing some of its millions of Guilders of opium profits into the eradication of smuggling, the Regie chose to keep the sizable proceeds as profit, ensuring the perpetuation of the problem and the consequent continuing profitable market for the legal drug.

A second characteristic of the Opium Regie was the price policy. The idea was to maintain a high price, ostensibly to discourage consumption. The Dutch school points to this as evidence of the sincerity of the Regie with respect to its stated goals. ${ }^{51}$ What it fails to acknowledge is the fact that a high price is also consistent with the behavior of a profit-maximizing monopolist. To the degree that the monopolist controls the market, it will raise the price of its product well above the cost of producing it, generating large profits. In fact, economic theory predicts a specific relationship between the price of the product and a measure of the cost of producing the good, if the producer is trying to maximize profits. ${ }^{52}$ In the simplest of frameworks, the theory predicts that the proportion of the price that is the mark-up over the marginal cost will be close to 1 if the producer is behaving like a profit-maximizing monopolist and has

49 As Rush states, "All of this [growth in sales of Regie opium] was good, and Ethical, because it helped snuff out the illegal trade in cheap - and, as the Dutch hastened to insist, inferior - opium. Only when the regie commanded the market could the vice tax principles on which it and the farm were based have any effect." Ibid., p. 235

50 Ibid., p. 230.

51 See, for example, discussion of the "rigorous" use in 1920-1921 of the "severe price policy" claimed in Van Ours, "Price Elasticity," p. 266. As discussed earlier, this was a rise in the money price brought about partly in response to a general rise in prices during the bad harvest years of 1920 and 1921. In "real" terms (i.e., in comparison to the prices of other goods), which is the correct economic measure of price, the price of opium actually fell during this time.

52 The measure of cost is the marginal cost of production. This is the cost incurred in order to produce one additional unit of output, in this case a specific amount of processed opium. 
Table 4: Sample Balance Sheet for the Opium Regie (for the year 1925$)^{\dagger}$

\begin{tabular}{|c|c|c|}
\hline Revenue & & \\
\hline Total revenue from sales & & $f 36,620,501.36$ \\
\hline $\begin{array}{l}\text { Value of the opium returned to the opium } \\
\text { factory on account of leakage or other defect }\end{array}$ & & $f 2,918.60$ \\
\hline Total revenue from sales & & $f 36,623,419.96$ \\
\hline Cost & & \\
\hline Cost of sold opium & $f 5,074,871.87$ & \\
\hline Cost of djitjing $\ddagger$ & $f 100,855.00$ & \\
\hline $\begin{array}{l}\text { Wages and salaries of directorate and } \\
\text { inspectorate staff in the head office }\end{array}$ & $f 136,865.39$ & \\
\hline $\begin{array}{l}\text { Other wages and salaries paid for } \\
\text { work done for the Regie }\end{array}$ & $f 1,527,657.41$ & \\
\hline $\begin{array}{l}\text { Transportation and living expenses for } \\
\text { Regie personnel }\end{array}$ & $f 67,024.90$ & \\
\hline $\begin{array}{l}\text { Transportation cost of opium, djitjing } \ddagger \\
\text { money, and packing materials }\end{array}$ & $f 176,852.92$ & \\
\hline $\begin{array}{l}\text { Printing, office materials, packing materials, } \\
\text { lighting, and similar costs }\end{array}$ & $f 34,862.02$ & \\
\hline Rent and maintenance of buildings & $f 212,455.60$ & \\
\hline $\begin{array}{l}\text { Payment to the Marine Department for the use } \\
\text { of steamships in anti-smuggling operations }\end{array}$ & $f 217,761.00$ & \\
\hline $\begin{array}{l}\text { Cost of land-based anti-smuggling operations, } \\
\text { including payments for seized contraband }\end{array}$ & $f 117,530.00$ & \\
\hline $\begin{array}{l}\text { Pensions, reduced pay, unemployment benefits etc. } \\
\text { (15\% of total salaries and wages, plus reduced } \\
\text { pay for discharged superfluous personnel) }\end{array}$ & $f 235,197.00$ & \\
\hline Total cost & & $f 7,901,933.11$ \\
\hline Net profit of the Opium Regie & & $f 28,721,486.85$ \\
\hline
\end{tabular}

Source: Verslag betreffende den Dienst der Optumregie, 1925, Bijlage No. 3, p. 36.

†Figures are in current Guilders.

$\ddagger$ Ditjing was the residual substance, or opium dross, left after opium was smoked. Because of its morphine content, this substance was recycled as an input into processed opium. 


\section{Siddharth Chandra}

substantial monopoly power. In other words, most of the price of the good is the profit-margin. In the case of the Regie, this number is close to 1 by empirical economic standards, suggesting profit-maximizing behavior by a monopolist.

A second specific prediction relating to the behavior of the Opium Regie has to do with the price-elasticity (or price-responsiveness) of consumption presented in Table 3. Economic theory predicts that a profit-maximizing monopolist will price his product such that the price-elasticity for that product is close to, but less than, -1 in value (for example, -1.20). In the specific case of an addictive good, however, the monopolist will lower his price so that the price-elasticity is greater than $-1(-0.95$, for example). The reason for this is that, in selling an addictive good, it is in the interest of a monopolist to lower the price to attract consumers, because the long-term benefit to him of having additional addicted consumers outweighs the short-term loss from lowering the price below what he would charge if the good were not addictive. ${ }^{53}$ In the case of the Opium Regie, the price elasticities for the Chinese and indigenous users are greater than -1 . This is consistent with profit-maximizing behavior by a monopolist in the market for an addictive good.

As a final note on the effects of price on opium consumption, it is ironic that the only situations in which high prices actually reduced consumption were not of the making of the Regie--they were the two shocks discussed previously, brought about by circumstances entirely external to the Opium Regie. In addition, the first price shock actually resulted in a drop in the "real" price of opium, suggesting that the contemporaneous rise in the general price level was responsible for that decline in opium consumption.

A third policy feature of the Opium Regie was the system of licensing and registration of users. This system was supposed to restrict the consumption of opium to a controlled group of users, with the ostensible goal of phasing out consumption in the long run. Purchases by users were supposed to be limited in frequency and size. 54 As was discussed earlier, during the period under consideration, the licensing policy underwent one major change. This was the relaxation, in 1927, of the licensing requirements. This step was taken in response to a rise in smuggling activity. Its effects are visible in the steep increase in the numbers of "unlicensed" users in that year, especially in the Outer Islands areas close to Singapore, such as Oostkust van Sumatra and Riouw. Rather than act decisively, using some of its sizable profits to thwart smuggling, the Opium Regie behaved like a cost-conscious monopoly that is threatened by the entry of a competitor into the market - it made it easier for consumers to buy its own product. 55 The budget for anti-smuggling enforcement, on the other hand,

\footnotetext{
53 See Gary Fethke and Raj Jagannathan, "Habit Persistence, Heterogeneous Tastes, and Imperfect Competition," Journal of Economic Dynamics and Control 20, 6-7 (June-July 1996): 1193-1207; and Gary S. Becker, Michael Grossman, and Kevin M. Murphy, "An Empirical Analysis of Cigarette Addiction," National Bureau of Economic Research Working Paper No. 3322, April 1990, pp. 28-33.

54 In fact, as is pointed out in Foster, "Prohibition as Superiority," p. 267, the policy had mixed success, at best.

${ }^{55} \mathrm{As}$ with its other questionable actions, there was a convenient excuse for increases in the size of the market for Regie opium. To quote Rush, writing on the early Regie period, "... for those who may have been embarrassed to explain regie profit-consciousness in terms of Dutch greed, there was an Ethical rationale. If the regie sold less than the farm had done, the black market must be expanding. Any growth in regie sales...
} 
stayed fairly constant, a clear sign that allocating additional money from the profits of the Opium Regie to the eradication of the problem was not high on the policy agenda.

\section{Conclusion}

In this paper, the causes and nature of the decline between 1914 and 1940 of the Opium Regie in the Netherlands Indies were examined. Contrary to the gist of some recent scholarship from the Netherlands, which echoes the denials that typify some of the writings of the Regie period described in Rush's Opium to Java and elsewhere, I have argued that conscious government policy had little if anything to do with any decline in opium consumption. ${ }^{56}$ The statistical data, a good indicator of the actions of the Opium Regie, show that Rush's conclusions about the early years of the Opium Regie remain valid for its later years. By way of extension of that work, it has been shown, first, that the fall in opium consumption was driven by two economic events whose origins were entirely external to the Opium Regie. These were the inflation of 1919-1922 and the Great Depression of 1929-1935. In contemporaneous accounts of opium smokers, and in the quantitative characterization of the responses of opium consumers to these events, evidence can be found of addictive behavior, negating a second conclusion in the economic literature about the non-addictive nature of opium. The response of the intense Chinese users as a group was driven to a larger degree by the number of drop-outs than was the response of the less intense indigenous users. The policy actions of the Opium Regie with respect to price, enforcement, and licensing were shown to be consistent with the behavior of a profit-maximizing monopolist in the market for an addictive good. The attitude of the Regie toward the opium problem and its consequences for Indies subjects are well-expressed in the description of an addict in a recently published memoir of an Indies citizen of the time:

Koki had another very bad habit, which was more or less condoned by the government at that time, because it brought in a tidy sum of money in extra tax ... Koki was addicted to opium ... She would ... hold [an opium pipe] over the flame, inhaling greedily. Then I would notice her eyes closing, rolling back in a half-dream, and she would lay there motionless ... Koki threw away her hardearned money that way ... 57

In the final analysis, Indonesia has the Great Depression, and not the Opium Regie, to thank for the decline of opium consumption in the years prior to her independence.

could be explained in terms of bringing a once clandestinely fed market into the orbit of the Opium Regie." Rush, Opium to Java, p. 235

56 For an example of denial during the Regie period, see Mineke Bosch's description of Aletta Jacob's reaction to the opium factory in Batavia, in Mineke Bosch, "Colonial Dimensions of Dutch Women's Suffrage: Aletta Jacob's Travel Letters from Africa and Asia, 1911-1912," Journal of Women's History 11,2 (Summer 1999): 8-34.

57 Marguerite Schenkhuizen, Memoirs of an Indo Woman: Twentieth-Century Life in the East Indies and Abroad, trans. Lizelot Stout van Balgooy (Athens, Ohio: Ohio University Center for International Studies, Southeast Asia Series No. 92, 1993), pp. 33-34. 
